Rok XVI (2021) | 2 (32) | S. 133-148

https://doi.org/10.12797/LV.16.2021.32.12

Licencja: CC BY-NC-ND 4.0

Zofia Sawaniewska-Mochowa •

Instytut Slawistyki Polskiej Akademii Nauk, Warszawa

zofia.sawaniewska-moch@ispan.waw.pl

Katarzyna Siewert-Kowalkowska

Uniwersytet Kazimierza Wielkiego, Bydgoszcz

ksiewert@ukw.edu.pl

\title{
GERMANIZMY EMOTYWNO-OCENIAJĄCE W GWARACH KUJAWSKICH: NAZWY OSÓB ${ }^{1}$
}

Słowa klucze: gwary kujawskie, germanizmy i ich zasięgi, słownictwo emotywno-oceniające, ekspresywność implicytna i eksplicytna

Keywords: Kuyavian dialect, Germanisms and their range, emotive-evaluative vocabulary, implicit and explicit expressiveness

\section{Wprowadzenie}

Kujawy - region położony w centrum polskiego obszaru językowego - historycznie pozostawały na styku różnych wpływów językowych i kulturowych: wielkopolskich, pomorskich, mazowieckich, niemieckich i rosyjskich. Przez ponad 100 lat były podzielone między dwa państwa zaborcze, Prusy i Rosję. Część zachodnia Kujaw (dawne województwo inowrocławskie) znalazła się w kręgu silnych oddziaływań niemieckich, część wschodnia (dawne województwo brzesko-kujawskie), wchodząca w skład Królestwa Kongresowego, podlegała wpływom rosyjskim. Dopiero na mocy traktatu wersalskiego z 1919 r. region został scalony i przywrócony odrodzonemu

1 Wkład współautorek jest równy i wynosi po 50\%. 
państwu polskiemu. Pozostawanie Kujaw z jednej strony w kręgu oddziaływań językowych i cywilizacyjnych niemieckich i rosyjskich, a z drugiej - w sferze wpływów gwar i kultur regionów sąsiednich skutkowało zróżnicowaniem zasobów kujawskiego słownictwa gwarowego. Nigdy jednak ten region, pomimo ważnej roli w dziejach polskiej państwowości i bogatej kultury ludowej, wielokrotnie opisywanej przez etnografów, nie stał się przedmiotem odrębnych studiów leksykalnych, które w sposób uporządkowany ukazałyby słownictwo Kujaw z punktu widzenia jego pochodzenia, semantyki i zasięgu geograficznego ${ }^{2}$. Jedyne dotychczas opracowanie monograficzne gwar kujawskich autorstwa Zenona Sobierajskiego (1952), jakkolwiek bardzo cenne, nie zawierało systematycznego przeglądu zagadnień leksykalnych. W obecnej sytuacji wszystkie dotychczasowe próby rejestrowania słownictwa gwarowego z terenu historycznych Kujaw (zob. SGKK: 13-15), także te XIX-wieczne, a zwłaszcza Stowniczek wyrazów kujawskich Oskara Kolberga $\left(\mathrm{K}_{4} \mathrm{Kuj}_{2}: 268-279\right)$, stanowią ważne źródła do prowadzenia badań leksykalnych. Współcześnie gromadzenie materiałów gwarowych podczas eksploracji terenowych jest już bardzo utrudnione, bo czynnych użytkowników gwar kujawskich nie ma zbyt wielu i są to zwykle osoby najstarsze. Pogląd Władysława Lubasia (2003: 211), że obecnie „czyste dialekty” są odmianami regresywnymi, ustępującymi na rzecz interdialektów, supradialektów, języków miejskich, możemy odnieść z całą pewnością do współczesnej sytuacji językowej Kujaw, wykazującej wiele zbieżności w zakresie słownictwa z polszczyzną potoczną i gwarami miejskimi (Bydgoszczy i Poznania). Interakcje zachodzące między gwarami, dialektami, różnymi formami postdialektalnymi a odmianą potoczną jeszcze mocniej podkreśla Renata Kucharzyk (w druku). Wykazuje ona, że przenikanie leksykalnych elementów gwarowych do słownictwa potocznego jest procesem dynamicznie zasilającym współczesne zasoby słownikowe Polaków, co uwidacznia się choćby w komunikacji internetowej.

\section{Rozumienie terminu germanizm}

Gerd Hentschel (1995: 70) zauważa, że badacze różnie definiują pojęcie germanizmu w języku polskim, co $\mathrm{w}$ dużej mierze wynika $\mathrm{z}$ różnych założeń przyjmowanych przez lingwistów w opisie (por. Witaszek-Samborska 1993: 19). Stanowisko morfosemantyczne konkuruje z leksykalistycznym. W pierwszym podejściu jako źródło zapożyczenia podaje się język, z którego etymologicznie pochodzi rdzeń danego lek-

2 Wprawdzie region, jego historia i granice, cechy gwarowe oraz starsze źródła słownikowe zostały dość szeroko zaprezentowane w witrynie Dialekty i gwary polskie. Kompendium internetowe pod redakcją Haliny Karaś (2010), jest to jednak ujęcie z założenia inne niż oparta na kryteriach semantycznych, geograficznych i etymologicznych charakterystyka kujawskiego słownictwa gwarowego pochodzenia niemieckiego. 
semu, w drugim - język, z którego dany leksem został bezpośrednio przejęty, bez względu na ewentualne języki pośredniczące w jego wędrówce do polszczyzny.

W szerokim rozumieniu za niemieckie pożyczki w polszczyźnie G. Hentschel (WDLP) uznaje leksemy, które przywędrowały do niej zasadniczo czterema drogami, co ilustruje schematycznie w następujący sposób:

$$
\begin{aligned}
& \text { I A } \rightarrow B ; \\
& \text { II } A \rightarrow R \rightarrow B ; \\
& \text { III } \mathrm{Q} \rightarrow \mathrm{A} \rightarrow \mathrm{B} ; \\
& \text { IV } \mathrm{Q} \rightarrow \mathrm{A} \rightarrow \mathrm{R} \rightarrow \mathrm{B} .
\end{aligned}
$$

Drogi I i III są charakterystyczne dla bezpośrednich zapożyczeń z języka niemieckiego (A) do języka polskiego (B), natomiast drogi II i IV przedstawiają drogę zapożyczeń, które z niemczyzny weszły do polszczyzny za pośrednictwem innych języków (R). Rolę takiego medium do około XVI w. odgrywał język czeski, a od końca XVIII w. język rosyjski. Wspólną cechą dróg I i II jest to, że zapożyczenia mają swoje źródło w niemczyźnie lub we wcześniejszej fazie jej historycznego rozwoju, w językach germańskich. Natomiast w wypadku dróg III i IV zapożyczenia przejęte do polszczyzny z języka niemieckiego mają swoje źródło w innym języku (Q), często $\mathrm{w}$ łacinie, ale także $\mathrm{w}$ językach romańskich, przede wszystkim włoskim i francuskim. Zapożyczenia przejęte według schematu I stanowią najbardziej oczywiste i jednocześnie prototypowe germanizmy w polszczyźnie.

$\mathrm{Z}$ uwagi na problemy związane $\mathrm{z}$ jednoznacznym ustaleniem między innymi pośrednictwa czeskiego w zapożyczaniu wyrazów pochodzenia niemieckiego do polszczyzny oraz niekiedy silnego wpływu niemczyzny na formę zewnętrzną i znaczenie leksemów przejmowanych za jej pośrednictwem do polszczyzny z innych języków (por. Karszniewicz-Mazur 1988: 266; WDLP) w artykule przyjmujemy szerokie rozumienie terminu germanizm $\mathrm{w}$ gwarach kujawskich, obejmujące cztery wyżej przedstawione drogi zapożyczeń. Do takiego podejścia skłania nas również ciągle nierozstrzygnięta kwestia ustalenia dróg przenikania leksemów niemieckich do słownictwa gwarowego, pomimo bogatej literatury na temat historii, asymilacji i żywotności germanizmów w języku polskim (por. Hentschel 2016). Mamy świadomość, że wiele z nich miało charakter wędrowny, a to skutkowało inną dynamiką rozpowszechniania się na różnych obszarach i w różnych środowiskach oraz terytorialnym i społecznym zniuansowaniem znaczeń. Analizą obejmujemy dwie grupy leksemów obcego pochodzenia, a mianowicie zapożyczenia właściwe, w których przejęcie dotyczy formy zewnętrznej (często z elementami substytucji fonetycznej i morfologicznej), jak i znaczenia wyrazu obcego, oraz derywaty od zapożyczeń, które są zjawiskiem pośrednim między zapożyczeniem a wyrazem rodzimym (por. Witaszek-Samborska 1993: 16). Pomijamy natomiast kalki i hybrydy, które zamierzamy omówić w innym opracowaniu. 


\section{Dobór materiału i kryteria analizy}

O wyborze słownictwa do tej z konieczności ograniczonej materiałowo analizy zadecydowało kryterium semantyczne i stylistyczne, interesują nas bowiem germanizmy w gwarach kujawskich, które obsługują stosunkowo wąski obszar rzeczywistości (są nacechowane antropocentrycznie i ekspresywnie³), wyrażają różne stany emocjonalne mówiących oraz najczęściej łączą się z waloryzacją ujemną, rzadko z wartościowaniem pozytywnym. Germanizmy nienacechowane również są obecne w zasobie leksyki kujawskiej jako nazewnictwo odnoszące się na przykład do sfery budownictwa czy transportu, ale te kategorie znaczeniowe nie będą przedmiotem opisu w tym artykule.

Badacze zapożyczeń leksykalnych z języków obcych w polszczyźnie zwracali uwagę na specyfikę wpływów germańskich, które zazwyczaj dotyczyły warstw słownictwa uważanego za "plebejskie" ${ }^{4}$, a „w czasach zaborów - jak zauważa Małgorzata Witaszek-Samborska (ibid.: 36) - oznaczały wpływ języka narzuconego, znienawidzonego, pożyczki te nigdy nie stały się w polszczyźnie wyrazami modnymi [...]". Według W. Lubasia (2003: 502) zapożyczenia z języków obcych prawie zawsze są nacechowane ujemnie lub pozytywnie w zależności od prestiżu języka, z którego zostały przejęte do polszczyzny. O jakości tego nacechowania decyduje dodatkowo zdaniem badacza - sposób przejęcia leksemu, to, czy został on wprowadzony do leksyki przez obcowanie z kulturą wyższą, czy w drodze wzajemnych kontaktów ludności w sferach życia codziennego.

W gwarach Kujaw przejmowanie zapożyczeń niemieckich, podobnie jak w przypadku innych odmian terytorialnych, mogło odbywać się w dwojaki sposób: na skutek bezpośrednich kontaktów autochtonicznej ludności z osadnikami niemieckimi oraz przez przyswajanie germanizmów o proweniencji literackiej, z którymi rdzenni mieszkańcy stykali się w kontaktach z obcą administracją, oświatą czy wojskiem w okresie zaboru pruskiego czy podczas okupacji niemieckiej w trakcie II wojny światowej.

Za nadrzędne w charakterystyce zapożyczeń niemieckich uznajemy kryterium semantyczno-stylistyczne, które pozwala odnieść badane przez nas jednostki do

3 Za ekspresywne uznajemy wyrazy, które przekazują określony stosunek emocjonalny nadawcy wobec osób, przedmiotów, czynności, zjawisk itp. Analizowane w artykule nazwy osób, zgodnie z najbardziej konsekwentną typologią ekspresywizmów leksykalnych zaproponowaną przez Stanisława Grabiasa (1981: 28, 39-40), charakteryzują się ekspresywnością implicytną (np. ekensztyjer, huncwot) lub eksplicytną (np. langus), a także różnym nacechowaniem, np. żart., iron., pogard. (por. Gruchmanowa, Witaszek-Samborska, Żak-Święcicka 1986: 48). Przegląd różnych stanowisk w kwestii rozumienia ekspresywności przedstawił Artur Rejter (2006: 58-71).

4 Taką konstatację znajdujemy także u Alicji Nagórko (1998: 336): „Materialne zapożyczenia z różnych języków odznaczają się swoistą wartością stylową, np. germanizmy należą na ogół do niskiego rejestru, rusycyzmy odznaczają się dodatkową aurą emocjonalną itp.". 
dziedziny życia codziennego, a więc do słownictwa, które nie należy do specjalnie wysokiego, prestiżowego rejestru, a służy ewokowaniu różnych emocji i ocen. Najwięcej uwagi poświęcamy śledzeniu relacji semantycznych, jakie zachodzą między podstawą zapożyczenia, nacechowaniem emocjonalno-oceniającym leksemu niemieckiego a funkcją ekspresywno-wartościującą germanizmów gwarowych, często zbieżną pod względem afektywnym z leksyką potoczną.

$\mathrm{Za}$ istotne kryterium klasyfikacyjne w charakterystyce leksemów gwarowych uznajemy również kryterium geograficzne. Celem jego zastosowania jest ustalanie zasięgów wyrazów i wyodrębnianie dialektyzmów wąsko- i szerokoterytorialnych. Ostateczne rozstrzygnięcia co do rozpowszechnienia i żywotności poszczególnych jednostek gwarowych nie zawsze są możliwe, niemniej jednak wyodrębnianie wyrazów specyficznie kujawskich, jak i poszukiwanie paralel leksykalnych z innymi regionami (nie tylko sąsiadującymi z Kujawami) pod względem obecności ekspresywizmów pochodzenia niemieckiego wydaje nam się poznawczo cenne, nawet jeśli byłoby tylko przyczynkiem do poznania wędrówek germanizmów w gwarach.

Słownictwo do przedstawionej niżej charakterystyki germanizmów emotywno-oceniających związanych z nazwami osób czerpiemy z 1. tomu Słownika gwary i kultury Kujaw (SGKK) oraz kartoteki tego leksykonu, który ma charakter diachroniczno-synchroniczny i rejestruje dane językowe na zasadzie „krzyżowania” różnorodnych źródeł: zastanych, w tym XIX-wiecznych i późniejszych, ze zgromadzonymi na początku XXI w. materiałami gwarowymi, zebranymi w terenie metodą ankiet leksykalnych i wywiadów częściowo ukierunkowanych. Baza empiryczna SGKK obejmuje także dane atlasowe, źródła etnograficzne, teksty folkloru (por. Sawaniewska-Mochowa 2016) oraz teksty literackie i paraliterackie, gawędziarskie i wspomnieniowe tworzone przez mieszkańców regionu, którzy wykorzystują autentyczne środki gwarowe swoich rodzinnych stron. Rezygnujemy jedynie z przyjętych w SGKK szczegółowych zasad lokalizacji materiału gwarowego, ograniczając się do ogólniejszych kwalifikatorów geograficznych. Sygnalizujemy też odpowiednim kwalifikatorem, z jakiego gatunku folkloru słownego został zaczerpnięty leksem gwarowy; stopień nacechowania ekspresywnych nazw ekscerpowanych z przekazów związanych z obrzędowością regionu (na przykład przywoływek/przywołówek dyngusowych, czyli wywoływania dziewcząt w pierwszy dzień Wielkanocy wieczo$\mathrm{rem}^{5}$ ) łączy się nierzadko $\mathrm{z}$ ich funkcjami satyrycznymi.

5 Przebieg tego zwyczaju, odnotowanego już przez Kolberga ( $\mathrm{K}_{3} \mathrm{Kuj}_{1}$ : 115), poprzedzającego właściwy dyngus w Poniedziałek Wielkanocny, nazewnictwo oraz funkcje ludyczno-towarzyskie i matrymonialne zostały obszernie udokumentowane w pracach etnografów (np. Przesławska 1974; Dunin-Karwicka 2000: 84-86; Szkulmowska 2006: 39). Z kolei analizę przywoływek z perspektywy językoznawczej przedstawiła Anna Paluszak-Bronka (2009). 


\section{Charakterystyka wybranych germanizmów emotywno-oceniających w gwarach kujawskich w aspekcie porównawczym}

Z obszerniejszego zbioru słownictwa kujawskiego pochodzenia niemieckiego wybieramy do analizy semantycznej, stylistycznej i etymologicznej nazwy odnoszące się do fizyczności i psychiki człowieka oraz oceniające go ze względu na status materialny. Stan posiadania był istotnym kryterium kategoryzowania ludzi w społeczności wiejskiej.

Pierwsza analizowana grupa, obejmująca 3 jednostki, to określenia fizyczności (wyglądu) człowieka, głównie nacechowane negatywnie. Leksem bela $\mathrm{z}$ formalnego punktu widzenia należy do zapożyczeń właściwych, ale w sensie onomazjologicznym jest przykładem derywacji semantycznej i pejoratywizacji dokonanej na gruncie rodzimym. W gwarach Kuj zach to pejoratywne określenie człowieka grubego (SGKK). Jako źródło tego germanizmu w polszczyźnie wskazywane są różne podstawy niemieckie i drogi zapożyczenia. Najbardziej przekonuje nas interpretacja SEBań i SZN, że bela weszła do polszczyzny za pośrednictwem daw. niem. regionalizmu bäle $\mathrm{z}$ ang. bale 'jednostka miary sukna', prawdopodobnie miejscem zapożyczenia był Gdańsk, który w czasach Hanzy importował z Anglii i Szkocji najlepsze sukna. SEBr podaje natomiast, że bela jest niemiecką pożyczką od rzeczownika Ballen, który początkowo stanowił wariant morfologiczny nazwy Ball 'kula, piłka', a następnie wyodrębnił się w zn. 'kłąb kciuka, przedstopie', później pod wpływem języka francuskiego również w zn. 'coś spakowanego, paka towaru' (Klu). Etymon Ballen przyjmuje również PSWP (IV: 26). Z kolei WSJP PAN odsyła przy nazwie bela w uogólnionym zn. 'gruby zwój jakiegoś materiału' do bela pot. 'gruba belka', derywat od belka, wskazując na śrwniem. balke 'duży kawałek drewna' ${ }^{\text {. W }}$ pol. pot. bela to 'korpulentna kobieta' bez nacechowania stylistycznego (SPLP za NSSPA: 8), lecz o ekspresywności implicytnej. Wyraz bela w zn. 'człowiek gruby' jako ekspresywizm został poświadczony z Wiel: A to bela! (SGP II: 38). Często występuje w gwarach we fraz. z czasownikami być, najeść się, spaść się, upić się jak bela (ibid.), które niosą negatywną ocenę wyglądu i zachowań człowieka. Z nadmiernym spożywaniem alkoholu jako działaniem społecznie nieakceptowanym wiążą się nacechowane pot. fraz. spićlupić/urżnać się jak bela 'mocno się upić' (rubaszne według SPP: 249), pijany, spity jak bela 'pijany do nieprzytomności' (PSWP IV: 27).

Pozostałe jednostki omawianej grupy to derywaty utworzone na gruncie języka polskiego za pomocą rodzimych formantów. Wyraz beka powstał od germańskiej pożyczki beczka i jest pospolitym, pejoratywnym określeniem człowieka grubego, używanym w gwarach kujawskich zwłaszcza w porównaniach: Jestem chłopisko jak beka, a niepodobny do człowieka [przywoływka] Kuj zach; tako grubo beka Kuj wsch (SGKK). Według SEBań beczka weszła do polszczyzny w zn. 'duże naczynie z drew-

6 Dawniej tkaniny, papier i inne materiały nawijano na podłużny kawałek drewna - belkę. Podobne uzasadnienie pochodzenia tego germanizmu w polszczyźnie znajdujemy w WDLP. 
nianych klepek' (XIV w.) i pochodzi ze stbaw. ${ }^{\star} b u t s ̌ a /{ }^{\star} b u t s ̌ e$. Dziś w dialekcie baw. Bütschen lub Butschen oznacza różne rodzaje naczyń, między innymi 'małą beczkę' i, co ciekawe, 'waginę', 'dziewczynę lekkich obyczajów', a także 'ładną, uroczą dziewczynę' (BWB). SEBr jako źródłosłów beczki podaje niem. rzeczowniki Butte 'otwarty zbiornik wykonany z klepek' (Klu) i Bottich 'beczka' (Grin) o proweniencji gniem. i płc. (Klu), zaznaczając jednak, że źródło to nie jest pewne. Leksem beka notuje także SPLP w zn. 'osoba korpulentna, tęga, zwykle niewysoka' oraz WSJP PAN 'osoba bardzo gruba'. W pol. pot. beka nie jest więc wyrazem nacechowanym stylistycznie, lecz nazwą o ekspresywności implicytnej. Bekę zarejestrowano jako emocjonalizm oceniający w gwarach Mp śr (o idzie jus ta beka!) oraz w porównaniach gruby jak beka z Łęcz i Kasz śr (SGP II: 34).

Nazwą o nacechowaniu żartobliwym jest langus 'wysoki mężczyzna lub chłopiec; dryblas, drągal': widzisz tygo langusa zgolonygo na połe? [gaw.] Kuj zach (SGKK). Podstawą derywatu jest niem. przymiotnik lang 'długi', do którego dodano sufiks -us, również co do pochodzenia obcy, nazywany w starszych gramatykach „sowizdrzalskim", produktywny w gwarach, tworzący liczne ekspresywne nazwy wykonawców czynności typu chlajus 'pijak', gnijus 'leń', pierdus 'plotkarz', łgus 'łgarz' (Cyran 1977: 98). Langus występuje w tym samym zn. i z taką samą ekspresywnością eksplicytną jak na Kujawach także w gwarze miejskiej Poznania (SGMP), natomiast w gwarze miejskiej Bydgoszczy ma zn. rozszerzone 'człowiek wysoki i chudy' (GMB). Inne źródła leksykograficzne tego wyrazu nie notują, odosobnione poświadczenie pochodzi z Pał 'drągal, dryblas' (Binkowski 2009: 52).

Drugą grupę znaczeniową wśród germanizmów emotywno-oceniających w gwarach kujawskich stanowią nazwy osób oddające aspekt psychiczny, zazwyczaj wartościujące człowieka negatywnie. Grupa ta obejmuje łącznie 8 jednostek leksykalnych, z których większość, tj. 7 ekscerptów, należy do zapożyczeń właściwych, a 1 jednostka jest derywatem utworzonym na gruncie rodzimym od zapożyczenia właściwego.

Nieakceptowanymi społecznie cechami są łobuzerstwo i chuligaństwo. Ocenianie osób z punktu widzenia nosicielstwa tych cech i zachowań społecznych, które są ich następstwami, znajduje odbicie w takich nazwach, jak: fagas, gałgan, huncwot i rojber. W gwarach kujawskich wyraz fagas jest pejoratywnym określeniem 'młodego chłopaka, niedorostka, łobuza' Kuj zach (SGKK), które wywodzi się od fagás, co w dialekcie dniem. oznacza 'włóczęga; owca' (SESł; SZN) i jako nazwa człowieka jest również nacechowane negatywnie. Co ciekawe, tylko w gwarach kujawskich fagas rozwinął pejoratywne zn. 'owczarz': Fagas - tak chłopi nazywaja z przekasem owczarzy ( $\mathrm{K}_{4} \mathrm{Kuj}_{2}: 270$, 279); także fugas: Owczarz, którego pogardliwie zowia czasem fugasem ( $\left.\mathrm{K}_{3} \mathrm{Kuj}_{1}: 58\right)$, co najprawdopodobniej łączy się ze wskazaną wyżej semantyką podstawy dniem. 'owca, skop' (SESł) ${ }^{7}$. Pejoratywizację nazwy fagas jeszcze

7 Fagas jako termin zootechniczny 'duża owca hodowana dla mięsa, wełny i mleka' potwierdza WSJP PAN. 
silniej rozwinęła pol. pot.: 'pogard. z niechęcią o mężczyźnie', 'pogard. o mężczyźnie wysługującym się, schlebiającym komuś', 'pogard. kelner, służący, lokaj, posługacz', 'cudzołożnik, kochanek zwykle zamężnej kobiety' i in. (SPLP). W gwarach pol. fagas to nazwa bardzo pojemna znaczeniowo, która wykazuje różne nacechowania, np.: pogard. 'o mężczyźnie' z Mp pn i Lub, 'o kobieciarzu' z Łęcz, pejor. 'o chłopcu' z Suw, Kraj, zdobrz; na Koc to 'łobuz, nicpoń' (SGP VII: 389).

Negatywną waloryzację człowieka odzwierciedla też gałgan 'nicpoń, urwis, łobuz’ ogkuj (SGKK), pochodzący od niem. Galgen, będącego obraźliwym określeniem 'złodzieja, łajdaka, nicponia'. Galgen to skrót od niem. złożenia Galgenschwengel 'nicpoń' (Gri; WDLP), zawierającego komponent Galgen 'szubienica' i Schwengel 'serce dzwonu' na oznaczenie 'powieszonego łotra, hultaja' (por. Klu) ${ }^{8}$. Gałgan ma również w pol. pot. nacechowanie negatywne: 'pot., pejorat.: łajdak' (WSJP PAN), 'nicpoń, łobuz, hultaj' (SPLP) i 'łobuz - energiczne dziecko' (ibid.). W gwarach pol. ( $\mathrm{w}$ tym $\mathrm{w}$ tekstach folkloru $\mathrm{z}$ różnych regionów) szeroko rozpowszechniony $\mathrm{w} \mathrm{zn}$. 'nicpoń, łajdak, hultaj, łobuz' (SGP VII: 115).

Do germanizmów emotywno-oceniających należy również huncwot 'szelma, psubrat': [...] jest już na sądzie boskim, ale jo myśle, że huncwot chyba diabłów zastawioł za siebie, bo wszyndzie go brali do granio, taki z niego był grocz [z tekstu sztuki Wesele na Kujawach Franciszka Becińskiego] (SGKK) i przestarzałe 'łobuziak, gagatek, psotnik, urwis': Huncwoty to takie psotne dzieci, które psikusy robia, broją. Ty huncwocie jeden - tak krzyczeli, jak dziecko coś narozrabiało ogkuj (ibid.). Wyraz ten jest zapożyczeniem właściwym $\mathrm{z}$ niem. Hundsfott 'obraźliwe określenie niegodziwego, a zwłaszcza tchórzliwego człowieka' (WDLP; Gri); pierwotnie było to bardzo ordynarne wyzwisko, ponieważ właściwie oznaczało 'pochwę suki' (Klu). Huncwot jest również negatywnie nacechowany w pol. pot., choć w WSJP PAN jest opatrzony kwalifikatorem książk.: 'o osobie, która zachowuje się źle, ale nie wyrządza wielkich szkód lub krzywd'. SPLP notuje leksem huncwot, co prawda bez dodatkowych kwalifikatorów: 'chłopiec lub młody mężczyzna sprawiający kłopoty wychowawcze, zachowujący się niesfornie, niegrzecznie' i 'wyzwisko', lecz poświadczone zn. wykazują wartościowanie ujemne tkwiące w nim implicite, w związku z tym pot. huncwot można uznać za wyraz o ekspresywności implicytnej. Huncwot potwierdzony został w bydgoskiej gwarze miejskiej w zn. 'łobuz, nicpoń' (GMB). Jako 'łobuz, nicpoń, hultaj' ma zasięg niemal ogólnogwarowy, rzadziej występuje w Wp i na Kasz (SGP X: 218).

Ostatnią nazwą odzwierciedlającą $\mathrm{w}$ gwarach kujawskich negatywną ocenę człowieka ze względu na jego nieakceptowane społecznie cechy i zachowania (chuligaństwo) jest rojber 'chłopiec naruszający normy współżycia społecznego, psotnik, chuligan' ogkuj (SGKK). Wyraz pochodzi od niem. Räuber 'kto dopuszcza się rabunku lub kto z rabunku uczynił sobie rzemiosło' (Gri). Podstawa niem. jest

8 Kołyszącego się na wietrze wisielca porównuje się z poruszającym się sercem dzwonu. 
nazwą o ekspresywności implicytnej, ponieważ brakuje tu zewnętrznego wykładnika emocjonalności, a waloryzacja ujemna 'rabuś, bandyta, zbój' jest zawarta implicite w samym wyrazie. Rojber to regionalizm kontaktowy poświadczony w zbliżonych zn. zarówno we współczesnym słownictwie śląskim: 'psotnik, chuligan' (FWBDL), 'rozrabiaka, łobuz' (SGŚ), 'drań, łotr, łobuz' (SGŚP), jak i w gwarze miejskiej Poznania: 'łobuziak, nicpoń, urwis' (SGMP) i Bydgoszczy (tu w zn. ograniczającym): 'dziecko lubiące robić psoty’ (GMB). W świetle KSGP nazwa ma zróżnicowane zasięgi semantyczne i geograficzne: na Śl, Mr i Kasz pn zachowuje zn. najbliższe podstawy niem. i oznacza 'zbója, bandytę, rabusia', natomiast w zn. 'zawadiaka, nicpoń' zarejestrowana została z Pał, jako ekspr. określenie 'łobuza' z Kraj i Koc.

$\mathrm{W}$ słownictwie kujawskim obecne są również zapożyczenia właściwe z niem., jak: ekensztyjer, lofer i lump, waloryzujące negatywnie człowieka ze względu na nieakceptowane społecznie cechy - próżniactwo i włóczęgostwo. Taką ocenę odzwierciedla nazwa ekensztyjer 'człowiek z marginesu społecznego, ulicznik': Pannice rzucały minchym jak pijane ekensztyjery [gaw.] Kuj zach (SGKK). Podstawę tego leksemu, użytego tylko w tekście kujawskiego gawędziarza Henryka Lewickiego, stanowi niem. Eckensteher 'obijający się próżniak' (Grin), będący złożeniem z Ecke 'róg' i Steher, rzeczownika nazywającego wykonawcę czynności od czasownika stehen 'stać. W DUW Eckensteher w zn. 'próżniak, który wystaje na rogach ulic' jest opatrzony kwalifikatorami pot., wychodzący z użycia. Z uwagi na brak zewnętrznego wykładnika emocjonalności zarówno nazwa pol., jak i niem. stanowią wyrazy o ekspresywności implicytnej.

Germanizmem o negatywnej waloryzacji jest również lofer, używany w gwarach kujawskich w odniesieniu do 'człowieka, który nie ma stałego zatrudnienia, lubi przebywać poza domem, włóczyć się, chodzić gdzie na plotki’ ogkuj (SGKK). Podstawą nazwy jest niem. Läufer, obocznie Laufer, który Gri poświadcza w zn.: 'biegacz', 'goniec, laufer', ale także 'ktoś, kto dużo biega' i tutaj odsyła do złożeń herumlaufer i landläufer 'włóczęga, wagabunda'. Ostatnie zn., które odzwierciedla lofer w gwarach kujawskich, w dzisiejszej niemczyźnie już nie funkcjonuje. Zarówno polską, jak i niemiecką nazwę można traktować jako wyrazy o ekspresywności implicytnej. Lofer w zn. 'łazęga, powsinoga' znany jest z gwary miejskiej Poznania (SGMP), w gwarze bydgoszczan to 'człowiek, który lubi przebywać poza domem, zmieniać miejsce przebywania', jak i 'niestateczny, niestały' (GMB). W pol. pot. lofer ma również nacechowanie pejoratywne, określa 'lenia, utracjusza' (SPLP). W gwarach nazwa nie jest zbyt rozpowszechniona, w zn. 'łazęga, powsinoga' KSGP dokumentuje z Wp i Maz; w zn. 'osoba lubiąca chodzić gdzie na plotki' z Kraj i Koc; loferl lojfer 'włóczykij, łazęga, powsinoga' na Pał (Binkowski 2009: 53).

Kolejnym zapożyczeniem niemieckim nacechowanym ujemnie w gwarach kujawskich jest lump, pogard. określenie 'człowieka z marginesu, który włóczy się po ulicach i odznacza się niechlujnym wyglądem i skłonnością do picia alkoholu' ogkuj (SGKK). Lump został w swojej formie i zn. przeniesiony do pol. z niem. Lump 
'człowiek w obszarpanym ubraniu, ubogi, nędzny, jednocześnie o nikczemnym usposobieniu’ na początku XX w. (WDLP; Gri). Niemiecka nazwa człowieka Lump rozwinęła się wtórnie z niem. Lumpen 'gałgan, szmata'. Ani polska, ani niemiecka nazwa osoby nie zawiera zewnętrznych wykładników emocjonalizacji, jej ekspresywność ma charakter asocjacyjny (zaniedbany, oberwany człowiek jest kojarzony $\mathrm{z}$ formą lumpy 'szmaty'). W pol. pot. lump to pogard. 'człowiek z marginesu społecznego, pozbawiony zasad moralnych; brudny, niechlujny, pijak i włóczęga' (WSJP PAN; SPLP). Lump 'drań' został ujęty także w słownictwie lektu śląskiego (FWBDL), lomp/lómp 'zły, niechlujny człowiek, oberwaniec' podaje też ze Śl SGŚP. W gwarach jest nazwą o szerokim zasięgu i zniuansowanym zn., potwierdzoną z Pał, Koc, Mp, Śl i Ciesz (KSGP).

Kolejną nazwą ujemnie wartościującą człowieka z powodu braku dbałości o wygląd i czystość jest fleja 'nieporządny, niechlujny, brudny', używana na Kuj zach w takich kontekstach: jak fleja wyglądasz, jesz jak fleja (SGKK), derywowana od niem. złożenia Fleituch, pochodzącego od flaien, fleien 'czyścić, prać' i Tuch 'materiał, szmatka, ścierka' (WDLP). W gwarach kujawskich ma nacechowanie pejoratywne i ekspresywność eksplicytną. Negatywna waloryzacja tej nazwy według WDLP to rezultat asocjacji z takimi desygnatami, jak szmata, ścierka, które kojarzą się z brudem. Postać flejalflyja 'człowiek brudny, nieporządny, niedbały, niechlujny' potwierdza ze Śl SGŚP. SGMP notuje fleję 'flejtuch, przede wszystkim o kobiecie' jako wyzwisko. Fleja i flejtuch są też negatywnie waloryzowane w pot. pol.: pejor. flejtuch (WSJP PAN), pogard. fleja (SPLP). Nazwa fleja jest udokumentowana z gwar regionów sąsiadujących z Kuj, zchełm, zdobrz, Maz pn (SGP VII: 570).

Ostatnią analizowaną grupę stanowią nazwy kategoryzujące człowieka ze względu na jego status materialny, które odzwierciedlają podziały społeczne (majątkowe) dawnej wsi. Grupa ta liczy 6 jednostek leksykalnych, z których 4 (bałor, betner/bytner, gbur, kietner) można uznać za zapożyczenia właściwe, a 2 (bamber, betnerok) za derywaty utworzone na gruncie rodzimym. Omawianą kategorię można podzielić na dwie podgrupy znaczeniowe: nazwy określające zamożnego gospodarza (bałor, bamber, gbur) oraz nazwy biednego chłopa (betner/bytner, betnerok, kietner) ${ }^{9}$.

9 Z komentarzy szczegółowych zamieszczonych w MAGP do map 446 (IX: 135-136) i 447 (ibid.: 138-140), odnoszących się do leksyki zgromadzonej niemal 7o lat temu, można by sądzić, że przywołane nazwy gospodarza pochodzenia niemieckiego, zarówno bogatego, jak i biednego, były niegdyś w gwarach kujawskich pozbawione ekspresji. Nie bez znaczenia dla naszych rozważań na temat germanizmów emotywnych pozostaje jednak uwaga ogólna zawarta w tym samym źródle, że wiele nazw zaznaczonych na mapie wspólnym znakiem ma często nacechowanie emocjonalne (ibid.: 137). Pod takim oznaczeniem kryją się np. szeregi synonimów bytner/betner, betnerok, bidok, mały gospodorz (Parchanie, pow. inowrocławski) czy kietner, papudråuk (Tryszczyn, pow. bydgoski), które z punktu widzenia nadawcy wcale nie muszą być aksjologicznie neutralne, a wybór konkretnej nazwy mógł zależeć od kategorii zamożności mówiącego. Do dostrzegania różnic w nacechowaniu emocjonalnym nazw osób w zależności od pozycji majątkowej informatora przekonuje nas spostrzeżenie eksploratora (najprawdopodobniej Huberta Górnowicza) zamieszczo- 
Wyraz bałor (też bałer) 'bogaty gospodarz', rzadko już dziś spotykany na Kujawach (SGKK), pochodzi od niem. Bauer, którego formy prefiksalne gibûr i gibûro, będące podstawą śrwniem. gebûr(e) (od niej z kolei wywodzi się pol. gbur), są poświadczone od VIII w., a postać bûr(e) jest udokumentowana od XIII w. Wymienione wyrazy były używane w trzech zn.: 'domownik, współmieszkaniec, sąsiad', 'ktoś (zależny, o niskim statusie) pracujący w rolnictwie; ktoś, kto prowadzi gospodarstwo (określany daw. terminem jako cały chłop i pótchłop w zależności od wyposażenia i wielkości zagospodarowanej powierzchni)' i pejor. '(w odniesieniu do deficytów przypisywanych chłopom) ograniczony intelektualnie, niewykształcony, grubianin, cham' (Grin). Pejoratywne zn. wyrazu Bauer funkcjonowało już w średniowieczu. Jak podaje Grin, Nikolaus von Jeroschin, pruski kronikarz żyjący w XIV w., określał rolnika wyrazem ackermann, kojarzonym także w czasach braci Grimm ze słowami szlachetniejszymi niż bauer, któremu przypisywano pospolitość, szorstkość i nieszlachetność i który służył do łajania chłopów. Z danych etymologicznych wynika, że element zn. 'bogaty' rozwinął się na gruncie polskim, być może w związku z cechą przypisywaną niemieckim osadnikom, ich umiejętnością dobrego gospodarowania będącego źródłem bogactwa. W takim zn. bauer jest obecny także w polszczyźnie ogólnej: 'bogaty rolnik zatrudniający pracowników najemnych' (WSJP PAN) i pol. pot.: 'bogaty chłop, zwłaszcza niemiecki, zatrudniający robotników' (SZN), choć w definicji 'chłop, gospodarz niemiecki' podanej w SPLP aspekt 'bogaty' nie został uwzględniony. W czasie okupacji leksem bałor nabrał zabarwienia negatywnego: Jeszcze bałor kozoł my robić, ale jo powiedziołym, że kóniec z pracom lu Mimców Koniń (SGKK). Nazwę bałer/bauer 'bogaty, zasobny gospodarz' rejestruje ze Śl SGŚ i SGŚP; natomiast w zn. 'gospodarz (w czasie okupacji wyraz nacechowany negatywnie)' zakwalifikowano w SGMP jako wychodzący z użycia i ekspr. Germanizm bałor (też bałer, bałór) jest jednostką szerokoterytorialną; w zn. 'bogaty gospodarz' notowany z Wp, Kasz pd, zdobrz, Mp zach, śr i pd-wsch oraz Śl, jako 'gospodarz niemiecki' z pog Kuj i Wp, Łęcz, Mp pd-wsch (SGP I: 438).

Wyraz bamber również określa 'bogatego gospodarza’ (SGKK), choć funkcjonuje także jako nazwa pogard. 'o kimś ze wsi, prostaku’: bamber mówić dobrze nie potrafit, tylko po wiejsku Kuj zach (ibid.). Bamber oznaczał najpierw osadników niemieckich sprowadzonych w XVIII w. do wsi pod Poznaniem z posiadłości biskupa z Bambergu w Bawarii. WDLP podaje za Gri, że bamber pochodzi od Bamberger, nazwy mieszkańca Bambergu, która miała w niem. odcień pejoratywny w zn. 'chłop'. Bamber jest więc derywatem wstecznym. Do pol. pot. bamber wszedł w zn. neutralnym 'mieszkaniec wsi' oraz trzech zn. nacechowanych: '(czasem z odcieniem pogard.) niem. chłop, wieśniak', 'pogard. chłop, gospodarz wiejski, mieszkaniec wsi' oraz '(o mężczyźnie) nieokrzesany, prostak, ordynarny, ciężko myślący’ w gwarze

ne na fiszce dokumentującej nazwę kietner: „biedny gospodarz w ustach małorolnych to swojak, w ustach bogaczy wiejskich kietner/kiejtner, w zn. ośmieszającym papudrok" (KSGP). 
studenckiej (SPLP). Bamber został zarejestrowany ze Śl, podobnie jak w gwarach kujawskich, w dwóch zn. 'gospodarz, rolnik' i przezw. 'gbur, nieokrzesaniec' (SGŚP), w SGŚ tylko jako 'gospodarz', FWBDL nie notuje. Także w gwarze miejskiej Poznania bamber funkcjonuje w dwóch zn.: 'chłop, szczególnie bogacz wiejski' i wyzw. pogard. 'o kimś ze wsi, prostaku' (SGMP). W GMB bamber 'mieszkaniec wsi pracujący na roli' jest wyrazem neutralnym. W zn. 'bogaty gospodarz' jest znany z Wp, Pał, zchełm, Koc, Kasz, Śl, a jako pejor. określenie 'mieszkańca wsi, człowieka nieokrzesanego' z Wp pn, Koc, Kasz (SGP I: 237).

Do grupy nazw określających bogatego gospodarza należy również gbur 'zamożny chłop, właściciel dużego gospodarstwa rolnego': Szostala, gbur nad gbury [z tekstu prozą] Kuj zach (SGKK). Wyraz ten pochodzi od śrwniem. formy gebûr 'współmieszkaniec wsi, sąsiad, chłop', ale także pejor. 'prostak' (SESł). Gwary kujawskie nie przejęły z niemczyzny zn. zabarwionego negatywnie, choć pejoratywizacja nazwy gbur 'człowiek nieokrzesany, ordynarny, prostak, cham' jest obecna w innych gwarach (SGP VIII: 243) i pol. pot. (SPLP). Gbur jest notowany ze Śl w SGŚP w dwóch zn. 'zamożny gospodarz' i przenośnie 'nieokrzesaniec, prostak'. Gbur w zn. 'bogaty gospodarz' jest wyrazem o szerokiej geografii, udokumentowanym z Wp pn i pd, Pał, Kraj, Bor Tuch, Koc, Kasz, Malb, Sztum, Lubaw, Ostr, zchełm, zdobrz, War, Mr, Maz, Śl pn (SGP VIII: 242-243).

Drugą podgrupę nazw osób oddających zróżnicowanie mieszkańców wsi pod względem stanu majątkowego stanowią dwa leksemy pochodzenia niem.: betnerl bytner (i poch. betnerok) oraz kietner. W związku ze zmianami cywilizacyjno-ekonomicznymi, jakie zaszły w społeczności wiejskiej, jednostki te straciły już żywotność. $Z$ powodu skąpych danych (por. przypis 9) trudno dziś ocenić, czy były to niegdyś nazwy neutralne, czy nacechowane emocjonalnie. Leksemy niem., które są podstawą tych zapożyczeń, nie są pozbawione elementu wartościującego. Betner 'biedny gospodarz', termin używany daw. na Kuj zach (SGKK), prawdopodobnie wywodzi się od niem. bettler 'ktoś, kto żyje z jałmużny' (Grin). Od podstawy betner utworzona została przy użyciu formantu -ok nacechowana nazwa betnerok 'biedny gospodarz' Kuj zach (SGKK). Gwarowy sufiks -ok wnosi silne zabarwienie ekspresywne, por. inne w gwarach kujawskich ekspresywizmy z tym formantem waloryzujące ujemnie ubogiego chłopa typu bidok, chudziok, papudrok czy paterok. W świetle dostępnych źródeł atlasowych i słowników gwarowych betner/bytner (i betnerok) jest leksemem poświadczonym tylko z Kuj zach (SGP II: 73). Z kolei nazwa kietner 'biedny gospodarz', według danych atlasowych znana tylko na pn od Bydgoszczy (Tryszczyn, Gościeradz), pochodzi najprawdopodobniej od niem. kötner, köthner 'posiadacz chałupy, małego lichego domu' (Gri). Podstawą tych rzeczowników jest z kolei śrdniem. kote, dziś Kate 'bardzo licha, biedna chałupa' (Klu; DUW). Wyraz Kate ma zabarwienie często pejoratywne (DUW), które prawdopodobnie przejęła nazwa Kätner 'mieszkaniec takiej chałupy', choć takiej informacji DUW nie notuje. W gwarach kietner/ketner/kiejtner 'chłop posiadający tylko dom lub dom i mały 
kawałek ziemi’ ma wyraźnie zasięg północnopolski (KSGP z Kraj, Bor Tuch, Koc, Sztum, zchełm i War).

\section{Wnioski}

W artykule zostało zaprezentowanych w ujęciu porównawczym 17 nazw określających w gwarach kujawskich człowieka w aspekcie jego fizyczności, psychiki i statusu materialnego, pochodzących $\mathrm{z}$ języka niemieckiego. $\mathrm{Z}$ formalnego punktu widzenia większość analizowanych germanizmów stanowiły zapożyczenia właściwe (12 jednostek), 5 - derywaty. Z kolei przeprowadzona analiza semantyczna materiału wykazała, że wśród pożyczek właściwych 6 jednostek (gałgan, huncwot, rojber, ekensztyjer, lofer, lump) zostało przejętych do gwar kujawskich z zachowaniem zn. i ekspresywności podstaw niem. (zaznacza się w gwarowych technikach nominacyjnych tendencja do zapożyczania $\mathrm{z}$ niem. nazw osób $\mathrm{z}$ waloryzacją negatywną). Trzy pożyczki właściwe (bałor, betner/bytner i kietner) weszły do polszczyzny gwarowej jako nazwy gospodarza oddające dawne podziały majątkowe mieszkańców wsi. MAGP nie precyzuje wprawdzie nacechowania tych leksemów, jednak biorąc pod uwagę znaczenie etymonów, nie możemy jednoznacznie wykluczyć ekspresywności implicytnej tych jednostek w gwarach kujawskich. Bogactwo i bieda są co prawda kategoriami relatywnymi, ale aksjologicznie nieobojętnymi.

Różnice w zakresie zn. i nacechowania ekspresywnego w stosunku do źródła niem. wykazują nieliczne jednostki słownikowe: fagas, który tylko w gwarach kujawskich stał się pejor. nazwą 'owczarza'; gbur, który nie przyjął obecnego w niem. odcienia pejor. 'chłop nieokrzesany, grubianin prostak' i oznaczał na Kuj zach, podobnie jak w gwarach północnopolskich, zamożnego gospodarza; z kolei leksem bela stał się ujemnie wartościującą nazwą człowieka otyłego przez asocjację z bela 'grubym zwojem jakiegoś materiału'. Derywaty beka, langus, fleja, betnerok, utworzone na gruncie rodzimym, zyskały najczęściej negatywny lub żartobliwy ładunek emocjonalny dzięki wykorzystaniu technik nominacyjnych służących tworzeniu ekspresywnych form gwarowych.

Spośród przeanalizowanych germanizmów kujawskich 9 jednostek (bela, beka, fagas, gałgan, huncwot, lofer, lump, gbur, bamber) jest obecnych w odmianie potocznej, silniejszej kolokwializacji i pejoratywizacji uległ w pol. pot. fagas, wyłącznie ekspresywizmem negatywnym stał się gbur, jako określenie pogard., a nawet wyzw. funkcjonuje bamber.

$\mathrm{Z}$ punktu widzenia kryterium geograficznego szerszy zasięg terytorialny, potwierdzony $\mathrm{z}$ więcej niż trzech regionów, mają takie germanizmy, jak: fagas 'łobuz', gałgan, huncwot (niemal ogólnogwarowy), lump, bałor, bamber i gbur jako 'bogaty gospodarz', jednostkami o węższym zasięgu są: bela, beka, fleja, langus, lofer 'łazęga, powsinoga', rojber 'łobuz, nicpoń' i kietner. W świetle dostępnych danych tylko z Kuj 
zach poświadczone zostały nazwy betner/bytner (i derywat betnerok), określające biednego gospodarza, oraz ekspresywizm ekensztyjer.

\section{Skróty nazw regionów i określeń geograficznych}

Bor Tuch - Bory Tucholskie; Ciesz - Cieszyńskie; Kasz - Kaszuby; Koc - Kociewie; Koniń Konińskie; Kraj - Krajna; Kuj - Kujawy (Kuj wsch - Włocławskie, Brzeskie, ok. Kowala, Kuj Nadwiślańskie; Kuj zach - Inowrocławskie, Radziejowskie, ok. Kruszwicy, Strzelna, niektóre gminy w pow. mogileńskim); Lub - Lubelskie; Lubaw - Lubawskie; Łęcz - Łęczyckie; Malb Malborskie; Maz - Mazowsze; Mp - Małopolska; Mr - Mazury; ogkuj - ogólnokujawskie; Ostr - Ostródzkie; Pał - Pałuki; pd - południowy; pn - północny; pog - pogranicze; Suw Suwalskie; Sztum - Sztumskie; Śl - Śląsk; śr - środkowy; War - Warmia; Wiel - Wieluńskie; Wp - Wielkopolska; wsch - wschodni; zach - zachodni; zchełm - ziemia chełmińska; zdobrz - ziemia dobrzyńska

\section{Pozostałe skróty}

ang. - angielski; baw. - bawarski; daw. - dawny, dawniej; dniem. - dolnoniemiecki; ekspr. ekspresywny; fraz. - frazeologizm; gaw. - gawęda; gniem. - górnoniemiecki; iron. - ironiczny; książka - książkowy; niem. - niemiecki; pejor. - pejoratywny; płc. - późnołaciński; poch. - pochodny; pogard. - pogardliwy; pol. - polski; pol. pot. - polszczyzna potoczna; pot. - potoczny; przezw. - przezwisko; stbaw. - starobawarski; śrdniem. - średnio-dolno-niemiecki; śrwniem. - średnio-wysoko-niemiecki; wyzw. - wyzwisko; zn. - znaczenie; żart. - żartobliwy

\section{Literatura}

Binkowsкi M.K., 2009, Mój słownik gwary pałuckiej, Żnin.

BWB: J. Denz i in. (red.), Bayerisches Wörterbuch, München 2020-, [on-line:] http://publika tionen.badw.de/de/bwb/index.

Cyran W., 1977, Tendencje stowotwórcze w gwarach polskich, Łódź.

Dunin-Karwicka T., 200o, Rola tradycji w kulturze wsi kujawskiej, Toruń.

DUW: Duden. Onlinewörterbuch, [on-line:] https://www.duden.de/woerterbuch.

FWBDL: G. Hentschel, J. Tambor, I. Fekete, Frequenzwörterbuch deutscher Lehnwörter im Schlesischen der Gegenwart. Mit Kommentaren zur Etymologie / Stownik frekwencyjny niemieckich zapożyczeń leksykalnych we wspótczesnym lekcie ślaskim. Z komentarzami etymologicznymi, Oldenburg 2021.

GMB: A.S. Dyszak, Gwara miejska bydgoszczan, Bydgoszcz 2015.

Grabias S., 1981, O ekspresywności języka. Ekspresja a stowotwórstwo, Lublin.

Gri: Deutsches Wörterbuch von Jacob Grimm und Wilhelm Grimm, [on-line:] https://www. woerterbuchnetz.de/DWB. 
GRIN: Deutsches Wörterbuch von Jacob Grimm und Wilhelm Grimm. Neubearbeitung (A-F), [on-line:] https://www.woerterbuchnetz.de/DWB2.

Gruchmanowa M., Witaszek-Samborska M., Żak-Święcicka M., 1986, Mowa mieszkańców Poznania, Poznań.

Hentschel G., 1995, Zur "Seuche” des deutschen Lehnwortes im Polnischen und zu den „Selbstheilungskräften” dagegen, [w:] A. Bochnakowa, S. Widłak (red.), Munus Amicitiae. Studia linguistica in honorem Witoldi Mańczak septuagenarii, Kraków, s. 69-78.

Hentschel G., 2016, Bibliographie zu deutschen Lehnwörtern im Polnischen und Kaschubischen, unter der Mitarbeit von B. Sieradzka-Baziur und D. Mika, Oldenburg, [on-line:] https://d-nb.info/1102549983/34.

$\mathrm{K}_{3} \mathrm{KuJ}_{1}$ : O. Kolberg, Dzieła wszystkie, t. 3: Kujawy, cz. 1, Wrocław - Poznań 1962 [1867].

$\mathrm{K}_{4} \mathrm{KuJ}_{2}$ : O. Kolberg, Dzieła wszystkie, t. 4: Kujawy, cz. 2, Wrocław - Poznań 1962 [1869].

Karaś H. (red.), 2010, Dialekty i gwary polskie. Kompendium internetowe, [on-line:] www. dialektologia.uw.edu.pl.

KARsZniewiCZ-MAzur A., 1988, Zapożyczenia leksykalne ze źródła niemieckiego we współczesnej polszczyźnie, Wrocław.

KLU: F. Kluge, Etymologisches Wörterbuch der deutschen Sprache, red. E. Seebold, Berlin Boston 2011, https://doi.org/10.1515/9783110223651.

KSGP: Kartoteka Słownika gwar polskich w Pracowni Dialektologii Polskiej Instytutu Języka Polskiego PAN, [on-line:] www.rcin.org.pl.

KuCHARzY K R., w druku, Słownictwo gwarowe w wypowiedziach internautów, [w:] D. Stolac, A. Vlastelić (red.), Generacija Interneta. The Internet Generation, t. 2, Zagreb - Rijeka.

Lubaś W., 2003, Polskie gadanie. Podstawowe cechy i funkcje potocznej odmiany polszczyzny, Opole.

MAGP: Mały atlas gwar polskich, t. IX, oprac. Pracownia Atlasu i Słownika Gwar Polskich Zakładu Językoznawstwa PAN w Krakowie pod kier. M. Karasia, red. M. Karaś, Z. Stamirowska, Wrocław - Warszawa - Kraków 1966.

NAGór Ko A., 1998, Synonimia kontekstowa i sytuacyjna. Implikacje leksykograficzne, „Prace Filologiczne" XLIII, s. 327-340.

NSSPA: M. Widawski, Nowy słownik slangu i potocznej angielszczyzny, wyd. 3, Gdańsk 2000.

Paluszak-Bronka A., 2009, O języku kujawskich przywoływek dyngusowych, „Linguistica Bidgostiana" VI, s. 82-91.

PrZesŁawska H., 1974, Przywoływki dyngusowe na Kujawach, Toruń.

PSWP: H. Zgółkowa (red.), Praktyczny słownik współczesnej polszczyzny, t. 4, Poznań 1995.

ReJTER A., 2006, Leksyka ekspresywna w historii języka polskiego. Kulturowo-komunikacyjne konteksty potoczności, „Prace Naukowe Uniwersytetu Śląskiego w Katowicach”, nr 2423, Katowice.

SAWANIEWSKa-Mochowa Z., 2016, Źródła etnograficzne i teksty folkloru jako baza empiryczna słownika gwarowego (na przykładzie Kujaw), „Język Polski” XCVI, s. 27-36.

SEBAń: A. Bańkowski, Etymologiczny słownik języka polskiego, t. 1-2, Warszawa 2000.

SEBR: A. Brückner, Słownik etymologiczny języka polskiego, Kraków 1927.

SESŁ: F. Sławski, Słownik etymologiczny języka polskiego, t. I-V, Kraków 1952-1982.

SGKK: Z. Sawaniewska-Mochowa (red.), Słownik gwary i kultury Kujaw, t. 1, Bydgoszcz 2017; także kartoteka słownika.

SGMP: M. Gruchmanowa, B. Walczak (red.), Słownik gwary miejskiej Poznania, wyd. 2 z suplementem, Warszawa - Poznań 1999. 
SGP: Słownik gwar polskich, red. M. Karaś (Źródła, t. 1), J. Reichan (t. 2-9, z. 2), S. Urbańczyk (t. 2-5), J. Okoniowa (t. 6-9, z. 2), B. Grabka (t. 7-9, z. 2), R. Kucharzyk (t. 9, z. 2-t. 10, z. 2), t. 1-3: Wrocław - Warszawa - Kraków 1977-1991, t. 4-10: Kraków 1992-2019.

SGŚ: A. Czajkowski i in. (red.), Słownik gwary śląskiej, wyd. 2 rozsz., Katowice 1998.

SGŚP: B. Podgórska, A. Podgórski, Słownik gwar śląskich. Godómy po naszymu, czyli po śląsku, Katowice 2008.

Sobierajski Z., 1952, Gwary kujawskie, Poznań.

SPLP: W. Lubaś (red.), Słownik polskich leksemów potocznych, t. 1-4, Kraków 2001-2006, [on-line:] www.rcin.pl.

SPP: J. Anusiewicz, J. Skawiński, Słownik polszczyzny potocznej, wyd. 2 popr., Warszawa Wrocław 1998.

Szkulmowska W., 2006, Ziemia rodzinna to Kujawy, cz. I: Słowo, Bydgoszcz.

SZN: M. Łaziński (red.), Słownik zapożyczeń niemieckich w polszczyźnie, Warszawa 2008. Wielki słownik języka polskiego PAN. Geneza, koncepcja, zasady opracowania, praca zbiorowa, red. P. Żmigrodzki, M. Bańko, B. Batko-Tokarz, J. Bobrowski, A. Czelakowska, M. Grochowski, R. Przybylska, J. Waniakowa, K. Węgrzynek, Kraków 2018.

WitaszeK-SAmborska M., 1993, Zapożyczenia z różnych języków we współczesnej polszczyźnie (na podstawie słowników frekwencyjnych), Poznań.

WDLP: A. Vincenz, G. Hentschel (red.), Wörterbuch der deutschen Lehnwörter in der polnischen Schrift- und Standardsprache, [on-line:] http://diglib.bis.uni-oldenburg.de/bisverlag/wdlp/46701.html.

WSJP PAN: P. Żmigrodzki (red.), Wielki słownik języka polskiego PAN, [on-line:] wsjp.pl.

\section{Emotive-Evaluative Germanisms in the Kuyavian Dialect: Names of Persons Abstract}

The article contributes to the knowledge on the sources of lexical borrowings from German into Polish dialects. The subject of the analysis includes selected names of persons that are Germanisms, characterized by expressiveness, and documented in the Kuyavian dialect. The vocabulary of this region has never been studied in this aspect. The material was taken from the $1^{\text {st }}$ Volume of The Dialect and Culture Dictionary of Kuyavia, and from its file. The term "Germanism" is understood broadly in this paper. Germanisms are considered not only as proper borrowings from the German language and dialects, but also as derivatives which were created in the native Kuyavian land on the basis of German original forms, using various nominative techniques. Four ways of penetrating the German influence into the Polish language were indicated. Various criteria were used in the analysis of these German loans: formal, etymological, semantic and geographical ones. A typology of expressivisms, developed by Stanisław Grabias, was utilised.

The article presents seventeen Germanisms in the Kuyavian dialect that define a man in terms of his physicalness, psyche and material status, in the context of the comparison with the semantically similar vocabulary in other regions of Poland and with non-general varieties of Polish. These are names that mostly reflect negative valuation (e.g. gatgan, fagas, huncwot, rojber, ekensztyjer, lofer, lump), and that are already present in the meanings and expressiveness of the German basic forms. 